\title{
Re-examination and phylogeny of the genus Chondrostoma based on mitochondrial and nuclear data and the definition of 5 new genera
}

\author{
Joana Isabel Robalo ${ }^{\mathrm{a}, \mathrm{b}, *}$, Vítor Carvalho Almada ${ }^{\mathrm{a}}$, André Levy ${ }^{\mathrm{a}}$, Ignacio Doadrio ${ }^{\mathrm{c}}$ \\ ${ }^{a}$ Unidade de Investigação em Eco-Etologia, Instituto Superior de Psicologia Aplicada, Rua Jardim do Tabaco 44, 1149-041 Lisboa, Portugal \\ ${ }^{\mathrm{b}}$ Departamento de Zoologia e Antropologia, Faculdade de Ciências, Universidade do Porto, Praça Gomes Teixeira, 4099-002 Porto, Portugal \\ ${ }^{\mathrm{c}}$ Museo Nacional de Ciencias Naturales, José Gutiérrez Abascal 2, 28006 Madrid, Spain
}

Received 30 March 2006; revised 24 June 2006; accepted 7 July 2006

Available online 20 July 2006

\begin{abstract}
Previous molecular phylogenetic studies of the genus Chondrostoma (Cyprinidae: Leuciscinae) were unable to resolve the relationship among its major species groups. In this paper we present a phylogeny for this genus, based on five mitochondrial genes and the nuclear gene $\beta$-actin, comprising a total of $4068 \mathrm{bp}$. Bayesian inference using all gene fragments yielded a fully resolved phylogeny, compatible with topologies obtained from individual fragments using maximum parsimony and minimum evolution. Mapping of morphological characters critical to the rasping feeding mode of most Chondrostoma species indicates that they evolved several times, and questions the use of these characters in the traditional definition of the genus. Our findings led us to the definition of the following new genera: Achondrostoma, Iberochondrostoma, Pseudochondrostoma, Protochondrostoma and Parachondrostoma. Our data contradict the hypothesis of a rapid radiation during Lago Mare phase, suggested by previous studies.
\end{abstract}

(C) 2006 Elsevier Inc. All rights reserved.

Keywords: Cyprinidae; Paleobiogeography; $\beta$-Actin; Character mapping; Taxonomic revision; New genera

\section{Introduction}

The genus Chondrostoma belongs to the family Cyprinidae, subfamily Leuciscinae (Zardoya and Doadrio, 1999; Durand et al., 2003; Nelson, 2006). This subfamily includes a large number of species distributed in mainland Eurasia (excluding Arabia, India, and Southeast Asia), Japan, and North America (Howes, 1991). Fish from the genus Chondrostoma are distributed throughout south and central Europe, from the Atlantic to the Caspian Sea, from the Mediterranean to the Baltic Sea. The genus is also present in Asia Minor, the Caucasus, and Mesopotamia (e.g., Elvira, 1997; Durand et al., 2003). Distribution maps are provided by Elvira (1987), Durand et al. (2003) and Doadrio and Carmona (2004).

\footnotetext{
${ }^{*}$ Corresponding author. Fax: +351 218860954.

E-mail addresses: jrobalo@ispa.pt (J.I. Robalo), mond147@ mncn.csic. es (I. Doadrio).
}

The number of species included in the genus varies according to the nature of data used to diagnose species, i.e., morphological and osteological features or molecular characters. Using mainly osteological characters, Elvira (1997), in his review of the genus, recognized 26 species. In that same year Bogutskaya (1997) described a new species from Turkey ( $C$. beysehirense), raising to 27 the number of species described in pure morphological grounds. Durand et al. (2003) characterized the Chondrostoma genus "by a mouth clearly subterminal, with transverse or arched slit, without barbell, and with the upper jaw forming a muzzle well-arched, with very hard oral lips and a sharp boarder". Molecular studies of cyprinids of Europe and Iberian Peninsula, based on the mitochondrial cyt $b$ gene (Zardoya and Doadrio, 1998, 1999), showed that the species included by Elvira (1997) in the genus Chondrostoma form a monophyletic clade that also includes species previously ascribed to the genus Rutilus Rafinesque, 1820. Some of these species had already been included in the genus Chondrostoma in 
earlier investigations (e.g. C. lusitanicum Collares-Pereira, 1980; C. lemmingii Steindachner, 1866, Collares-Pereira, 1983). The variation of criteria among authors and the discrepancies between molecular and morphological data generated a troublesome situation concerning the delimitation of the genus Chondrostoma, which remains as yet unresolved.

The recent findings of new Chondrostoma species in the Iberian Peninsula illustrate well the current state of affairs. Four new species of Chondrostoma have been described, which lack the horny layer on the lower lip, considered by some authors to be an important diagnostic feature of the genus (Elvira, 1987, 1997): C. almacai (Coelho et al., 2005), C. occidentale (Robalo et al., 2005), C. oretanum (Doadrio and Carmona, 2003a) and $C$. sp. (a species from the Duero basin which had been ascribed to $C$. lemmingii in earlier studies, Doadrio and Elvira, unpublished). Thus, data obtained from morphology and from cyt $b$ sequences are decoupled in this genus (Durand et al., 2003) and some authors consider that the mouth-related characters lack phylogenetic utility (Doadrio and Carmona, 2004). Overall, 35 species are included in the genus, if we consider those that had been placed there on morphological and or molecular grounds.

All molecular studies using the mitochondrial cyt $b$ gene led to the identification of a number of very well-supported lineages of Chondrostoma (e.g., Doadrio and Carmona, 2004), although the relationships among these groups were unresolved. The recovery of polytomies rather than bifurcating relationships may reflect lack of phylogenetic signal or the presence of rapid cladogenetic events. A rapid succession of several independent cladogenetic events may be empirically indistinguishable from a lineage-level polytomy, if internodes are so short that no mutations occur to distinguish daughter clades (Slowinski, 2001; Poe and Chubb, 2004). If internodes are large enough, using several independent gene fragments, even though each fragment many contain a faint phylogenetic signal, one may be able to detect a central tendency among gene histories, revealing previously hidden phylogenetic relationships (Page and Holmes, 1998; Poe and Chubb, 2004).

There is a wide consensus pointing to an Asian origin of the cyprinid colonization of Europe during the Oligocene, when the Turgai Sea (which separated the two continents) dried out (Briggs, 1995). Concerning the colonization of the South European peninsulas, two hypotheses have been proposed: (1) dispersion around the Mediterranean Sea during the Lago Mare phase of the Messinian salinity crisis (originally proposed by Bianco, 1990) and (2) an older and more gradual colonization of the Mediterranean waters through river captures from central Europe (originally proposed by Banarescu, 1992).

The Lago Mare hypothesis assumes that a major leuciscin radiation, which shaped the major lineages of the Mediterranean leuciscins, occurred during the Messinian salinity crisis (about 5.5 MYA) when the Mediterranean suffered a drastic drop in salinity allowing a very quick dispersal of leuciscins around the entire basin (Bianco, 1990).
The second hypothesis assumes that leuciscins invaded central Europe from Asia and colonized the southern peninsulas in the Oligocene, before the alpine orogeny isolated central from south Europe (formation of the Alps, Pyrenees, among other mountain chains) (Banarescu, 1992).

Recently, Doadrio and Carmona (2003b) called attention to the fact that the two hypotheses are not entirely incompatible. The southern dispersal route, suggested by Bianco (1990), has widespread acceptance and has now been incorporated into Banarescu's north dispersal theory (Banarescu and Coad, 1991). The current synthesis to explain the biogeography of European cyprinid fishes is based on two assumptions: (1) European cyprinids originated in Asia and (2) subsequently dispersed via two routes. Central European taxa dispersed from the north in the early Miocene, through water captures (rivers or lakes), while endemic freshwater fauna from the Mediterranean area dispersed via the southern route across the Mediterranean Sea, when it was oligohaline in the late Miocene.

Several authors have attempted to test these hypotheses using molecular data from different genera and different molecular clock calibrations for cyt $b$ (Zardoya and Doadrio, 1999; Durand et al., 2003; Doadrio and Carmona, 2003b, 2004). For the genus Chondrostoma and considering a molecular clock of $1 \%$ divergence per MY, Durand et al. (2003) found evidence that suggests a relatively recent colonization event of the western Palaearctic area in the Messinian (5.5 MYA), thus favouring the Lago Mare hypothesis (Bianco, 1990). The inability to solve the polytomous relationships among the main clades of Chondrostoma was taken by Durand et al. (2003) as evidence for its very rapid radiation. Doadrio and Carmona (2003b, 2004) using a similar value for the molecular clock achieved different results. According to these authors, the main Chondrostoma lineages originated in the Middle Miocene (in the Tortonian, approximately 11 MYA) and diversified only during the Pliocene (during the formation of the current river system), thus rejecting the Lago Mare dispersal hypothesis for this genus. The discrepancy between studies may be due to an inadequate interpretation of the molecular clock on behalf of Durand et al. (2003), namely using the $1 \%$ rate of sequence divergence between lineages as the rate of accumulation of mutation within each lineage (Doadrio and Carmona, 2003b, 2004).

Using the mitochondrial genes $12 \mathrm{~S}, 16 \mathrm{~S}$, cyt $b$, d-loop (control region), and tRNA-Phe and the nuclear gene $\beta$ actin, and including a number of additional species we address the heretofore polytomous relationship among major Chondrostoma lineages and provide a new, dichotomous phylogenetic hypothesis. A total of 22 of the 35 species included in the genus were analysed. In addition, we mapped the morphological traits traditionally used to define the genus, to infer their evolutionary history and to test whether they are sufficient to diagnose Chondrostoma as a monophyletic entity. Because these characters relate to mouth structures, strongly implied in the feeding mode of many Chondrostoma species, they are likely liable to parallel or 
convergent evolution. Indeed, if the ancestors of Chondrostoma fed by scrapping algae from rocks any modifications of the mouth that would improve its rasping efficiency could possibly be favoured by selection. Thus, we also mapped dorsal and anal fins rays and lateral scale counts, traits that are probably independent of feeding mode.

\section{Methods}

\subsection{Taxon sampling}

The taxa analysed in this study, their collection sites and their corresponding GenBank sequence Accession Nos. are listed in Table 1. We also included Anaecypris hispanica, Rutilus rutilus and Telestes souffia. Except in the few cases when not enough biological material was available, the DNA used for PCR and sequencing of all fragments came from the same individual. A. hispanica was used as outgroup in all analyses. This species was chosen because it is a leuciscin that, in previous molecular studies, using both mitochondrial and nuclear DNA, proved to be basal to the remaining species analysed (Zardoya and Doadrio, 1999; Robalo et al., 2006a). This option was adopted to leave the species more closely related with Chondrostoma in the ingroup, to test if Chondrostoma was shown by the analysis to be form a monophyletic clade. Voucher specimens are preserved in the fish collections of Museo Nacional de Ciencias Naturales (MNCN) and the Unidade de Investi- gação em Eco-Etologia, Instituto Superior de Psicologia Aplicada (UIEE/ISPA).

\subsection{DNA analysis}

Total genomic DNA was extracted from fin clips preserved in ethanol by an SDS/proteinase-k based protocol (adapted from Sambrook et al., 1989). For the $\beta$-actin gene a total of $939 \mathrm{bp}$ was amplified using the primers BactFor5'-ATGGATGATGAAATTGCCGC-3' and BactRev5'AGGATCTTCATGAGGTAGTC-3' (Robalo et al., 2006a). PCR conditions followed those in Robalo et al. (2006a). The amplification process was conducted as follows: 35 cycles of $\left[94^{\circ} \mathrm{C}(30 \mathrm{~s}), 55^{\circ} \mathrm{C}(40 \mathrm{~s})\right.$ and $72^{\circ} \mathrm{C}(1 \mathrm{~min}$ $30 \mathrm{~s})]$. The amplified fragment is homologous to a region of the $\beta$-actin gene of Cyprinus carpio (GenBank: M24113), including introns $\mathrm{B}$ and $\mathrm{C}$ and three exons.

For the cyt $b$ gene a total of 1029 bp was amplified using the primers LCB1-5'-AATGACTTGAAGAACCACC GT-3' (Brito et al., 1997) and HA-5'-CAAC GATCTCCG GTTTACAAGAC-3' (Schmidt and Gold, 1993). PCR conditions followed those in Cunha et al. (2004). The amplification process was conducted as follows: 25 cycles of $\left[94^{\circ} \mathrm{C}\right.$ $(1 \mathrm{~min}), 50^{\circ} \mathrm{C}(1 \mathrm{~min})$ and $\left.72^{\circ} \mathrm{C}(2 \mathrm{~min})\right]$.

A mitochondrial fragment was amplified using the primers DL1 5'-ACCCCTGGCTCCCAAAGC-3' (Liu et al., 2002) and 12Sstartrev 5'-GCTGGCACGAGTTTTACC GGC-3' (Robalo, unpublished), which recovers the

Table 1

Taxa analysed in this study, their sites of origin and their GenBank Accession numbers

\begin{tabular}{|c|c|c|c|c|c|c|}
\hline & River/Basin/Country & $12 \mathrm{~s}$ & $16 \mathrm{~s}$ & d-loop-tR NAPhe-12S & Cyt $b$ & $\beta$-Actin \\
\hline \multicolumn{7}{|l|}{ Chondrostoma } \\
\hline almacai & Arade and Mira/Arade and Mira/Portugal & DQ447669 & DQ447693 & DQ455031 & $\mathrm{AF} 045986 *$ & DQ447717 \\
\hline arcasii & Adaja/Duero/Spain & DQ455023 & DQ447689 & DQ455042 & DQ447730 & DQ447711 \\
\hline arrigonis & Cabriel/Jucar/Spain & DQ447684 & DQ447699 & DQ455025 & DQ447734 & DQ447714 \\
\hline duriense & Sabor/Duero/Portugal & DQ447673 & DQ447705 & DQ455033 & AF $045983 *$ & DQ447715 \\
\hline genei & Arno/Arno/Italy & DQ447677 & DQ447706 & DQ455038 & AF 533766* & DQ061938 \\
\hline lemmingii & Almonte/Tagus/Spain & DQ447668 & DQ447707 & DQ455027 & DQ447733 & DQ447716 \\
\hline lusitanicum & Colares and Samarra/Colares and Samarra/Portugal & DQ447670 & DQ447694 & DQ455043 & AY254584* & DQ447718 \\
\hline knerii & Trebizat/Neretva/Bosnia-Herzegovina & DQ447680 & DQ447702 & DQ455030 & DQ447739 & DQ447724 \\
\hline miegii & Cadagua/Nervion/Spain & DQ447665 & DQ447692 & DQ455026 & DQ447732 & DQ455049 \\
\hline nasus & Mures/Rhone/France & DQ447667 & DQ447691 & DQ455047 & DQ447729 & DQ447726 \\
\hline occidentale & Alcabrichel/Alcabrichel/Portugal & DQ447672 & DQ447695 & DQ455044 & AY254585* & DQ447720 \\
\hline oligolepis & Tornada/Tornada/Portugal & DQ447671 & DQ447696 & DQ455032 & AY254679* & DQ447713 \\
\hline oretanum & Robledillo/Guadalquivir/Spain & DQ447678 & DQ447700 & DQ455041 & DQ447737 & DQ447722 \\
\hline oxyrhynchum & Rubas/Rubas/Russia & DQ447676 & DQ447708 & DQ455035 & AF095606* & DQ447721 \\
\hline phoxinus & Suiça/Cetina/Bosnia-Herzegovina & DQ447679 & DQ447701 & DQ455029 & DQ447738 & DQ447723 \\
\hline polylepis & Azambuja/Tagus & DQ447674 & DQ447703 & DQ455034 & AF045982* & DQ061945* \\
\hline prespense & Prespa Lake/Prespa/Greece & DQ447682 & DQ447697 & DQ455046 & DQ447735 & DQ061944* \\
\hline$s p$ & Yeltes/Duero/Spain & DQ447666 & DQ447690 & DQ455048 & DQ447741 & DQ447712 \\
\hline soetta & $\mathrm{Po} / \mathrm{Po} /$ Italy & DQ447681 & DQ447709 & DQ455045 & DQ447740 & DQ061939* \\
\hline turiense & Mijares/Mijares/Spain & DQ447683 & DQ447698 & DQ455040 & DQ447731 & DQ061946* \\
\hline vardarense & Aoos/Aoos-Vjose/Greece & DQ447675 & DQ447704 & DQ455039 & $\mathrm{AF} 090749 *$ & DQ447719 \\
\hline willkommii & Arenoso/Guadalquivir/Spain & DQ447685 & DQ447710 & DQ455028 & DQ447736 & DQ447725 \\
\hline Anaecypris hispanica & Caia/Guadiana/Portugal & DQ447662 & DQ447686 & DQ455024 & AJ427814* & DQ061936* \\
\hline Telestes souffia & Saone/Rhone/France & DQ447663 & DQ447688 & DQ455037 & DQ447728 & DQ061950* \\
\hline Rutilus rutilus & Açores/Portugal & DQ447664 & DQ447687 & DQ455036 & DQ447727 & DQ061948* \\
\hline
\end{tabular}

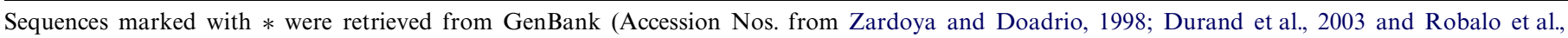
2006a,b). 
d-loop-control region (915 bp), the tRNA-Phe gene (69 bp) and the beginning of the $12 \mathrm{~S}$ gene (167 bp). PCR conditions followed those in Liu et al. (2002). The amplification process was conducted as follows: 2 min at $94{ }^{\circ} \mathrm{C}, 40$ cycles of $\left[94^{\circ} \mathrm{C}(30 \mathrm{~s}), 50^{\circ} \mathrm{C}(30 \mathrm{~s})\right.$ and $\left.72^{\circ} \mathrm{C}(1.5 \mathrm{~min})\right]$. An additional fragment of the $12 \mathrm{~S}$ gene $(395 \mathrm{bp})$ was amplified, using the primers $12 \mathrm{~S}$ For $5^{\prime}$-AAC TGG GAT TAG ATA CCC CAC-3' and 12SRev 5'-GGG AGA GTG ACG GGC GGT GTG-3' for a total of 562 bp of this gene. For the $16 \mathrm{~S}$ gene a total of $554 \mathrm{bp}$ was amplified using the primers 16SFor 5'-AAG CCT CGC CTG TTT ACC AA-3' and 16SRev 5'-CTG AAC TCA GAT CAC GTA GG-3'. For $12 \mathrm{~S}$ and $16 \mathrm{~S}$ rDNA, primers and PCR conditions follow those in Almada et al. (2005). The amplification process was conducted as follows: $4 \mathrm{~min}$ at $94^{\circ} \mathrm{C}, 30$ cycles of $\left[94^{\circ} \mathrm{C}\right.$ $(1 \mathrm{~min}), 55^{\circ} \mathrm{C}(1 \mathrm{~min})$ and $\left.72^{\circ} \mathrm{C}(1 \mathrm{~min})\right], 10 \mathrm{~min}$ at $72^{\circ} \mathrm{C}$.

For all genes, each sample was sequenced in both directions using the PCR primers. Sequencing reactions were performed by Macrogen Inc., (Seoul, Republic of Korea) in a MJ Research PTC-225 Peltier Thermal Cycler using a ABI PRISM BigDyeTM Terminator Cycle Sequencing Kits with AmpliTaq DNA polymerase (FS enzyme) (Applied Biosystems), following the protocols supplied by the manufacturer.

\subsection{Data analysis}

Sequences aligned with BioEdit ${ }^{\circledR}$ v.5.0.6. were analysed using distance (minimum evolution, ME) and maximum parsimony (MP) methods, using PAUP* 4.0 (Swofford, 1998). ME (neighbour-joining, NJ) trees were generated using maximum likelihood distances and random tie breaks. Molecular evolution models were selected using AIC criterion, as implemented in Modeltest (Posada and Crandall, 1998). MP topologies were sought using a 10 replicate heuristic search with random stepwise additions followed by tree-bisection-reconnection (TBR) branch swapping. The incongruence length difference test (Farris et al., 1995, as implemented in PAUP* 4.0) was used to access the homogeneity of the $12 \mathrm{~S}, 16 \mathrm{~S}$ and tRNA-Phe genes, and the exons and introns of $\beta$-actin. As no statistically significant differences were found, MP and ME analyses were performed separately on the following subsets: 12S-16S-tRNA-Phe, cyt $b$, d-loop and beta-actin.

For each gene, the saturation of transitions and transversions was checked by plotting the absolute number of changes of each codon position against uncorrected sequence divergence values $(p)$. There was no evidence of saturation in the ingroup (graphs not shown). Thus, we gave equal weights to transitions and transversions when performing the MP trees. Giving transversions 10 times the weight of transitions did not affect the results.

Bootstrap analyses (1000 replicates) were used to assess the relative robustness of branches of the ME and the MP trees (Felsenstein, 1985). Bayesian analysis was performed using MCMC as implemented in Mr. Bayes 3.1 (Ronquist and Huelsenbeck, 2003), with four independent runs of five
Metropolis-coupled chains of 2,000,000 generations each, to estimate the posterior probability distribution. The full sequence matrix was partitioned per gene fragment, and the nuclear beta-actin gene was partitioned into an exon and intron partition, making a total of seven data partitions. Independent model parameters $(\mathrm{GTR}+\Gamma+\mathrm{I})$ were estimated for each partition. The heating parameter was set to 0.15 , topologies were sampled every 100 generations, and a majority-rule consensus tree was estimated after discarding the first $10^{5}$ generations.

To access congruence between the more fully resolved Bayesian phylogeny (based on all gene fragments) and the ME and MP trees based on partial data sets, we compared the latter trees with trees obtained by the same method, but imposing the Bayesian topology as a constraint. Independently, we adopted the same procedure to compare constrained and unconstrained ME and MP trees of the partial datasets using relevant features of the Bayesian tree as constraints: the monophyly of the Iberian species, topological relationships within the Iberian clade, monophyly of the Italo-Balkanic group ( $C$. kneri, C. phoxinus, $C$. soetta), monophyly of the nasus group, monophyly of all non-Iberian species with exclusion of the basal $C$. genei and dichotomy between $C$. genei and a clade comprising all remaining Chondrostoma species. Constrained and unconstrained trees were compared statistically using Kishino and Hasegawa (1989) and Shimodaira and Hasegawa (1999) tests, as implemented in PAUP*.

\subsection{Character mapping}

Information concerning several meristic characters was gathered from the literature (Collares-Pereira, 1983; Elvira, 1987; Doadrio, 2001) and from available specimens: presence/absence of horny layer on lower lip, position and arching of mouth, number of scales on the lateral row, and number of dorsal and anal fin rays. Character history was mapped on the best resolved phylogenetic tree, i.e., the Bayesian topology. Ancestral states were reconstructed under a maximum-parsimony method, considering ordered character states with equally weighted transitions, using Mesquite v. 4.5.2 (Maddison and Maddison, 2005).

\section{Results}

A total of $4068 \mathrm{bp}$ was amplified. Of these, $3129 \mathrm{bp}$ correspond to mitochondrial DNA and $939 \mathrm{bp}$ to the nuclear gene of $\beta$-actin. Details of MP and ME analyses are summarized in Table 2. No bootstrap analysis was performed on MP reconstruction for $\beta$-actin, due to the high number of most parsimonious trees obtained (7910 trees). In Fig. 1, we present the results of the Bayesian analysis using the entire data set. This phylogeny presents a complete resolution of relationships within the genus, and is entirely compatible with all other trees obtained using MP and ME inference on each DNA fragment (see supplementary material for MP e ME trees, and statistical comparison of these 
Table 2

Results of the ME and MP analysis

\begin{tabular}{|c|c|c|c|c|}
\hline & 12S-16S-tRNAPhe & Cyt $b$ & d-Loop & $\beta$-Actin \\
\hline \multicolumn{5}{|l|}{ MP analysis } \\
\hline Number of parsimony informative characters & 67 & 255 & 118 & 23 \\
\hline Number of most parsimonious trees obtained & 34 & 3 & 5 & 7910 \\
\hline Consistency index & 0.60 & 0.48 & 0.57 & 0.87 \\
\hline Tree length & 230 & 907 & 469 & 74 \\
\hline Retention index & 0.64 & 0.54 & 0.58 & 0.87 \\
\hline Homoplasy index & 0.40 & 0.53 & 0.43 & 0.14 \\
\hline Rescaled consistence index & 0.38 & 0.26 & 0.33 & 0.75 \\
\hline \multicolumn{5}{|l|}{ ME analysis } \\
\hline Model selected by Modeltest (AIC criteria) & $\operatorname{TrN}+\mathrm{I}+\mathrm{G}$ & $\mathrm{GTR}+\mathrm{G}+\mathrm{I}$ & $\mathrm{TIM}+\mathrm{I}+\mathrm{G}$ & K81uf + I \\
\hline \multirow[t]{4}{*}{ Nucleotide proportions } & $\mathrm{A}=0.29$ & $\mathrm{~A}=0.28$ & $\mathrm{~A}=0.32$ & $\mathrm{~A}=0.21$ \\
\hline & $\mathrm{C}=0.26$ & $\mathrm{C}=0.31$ & $\mathrm{C}=0.21$ & $\mathrm{C}=0.25$ \\
\hline & $\mathrm{G}=0.23$ & $\mathrm{G}=0.14$ & $\mathrm{G}=0.14$ & $\mathrm{G}=0.22$ \\
\hline & $\mathrm{T}=0.22$ & $\mathrm{~T}=0.28$ & $\mathrm{~T}=0.32$ & $\mathrm{~T}=0.32$ \\
\hline Assumed proportion of invariable sites & 0.79 & 0.57 & 0.53 & 0.87 \\
\hline Alpha & 0.64 & 1.14 & 0.57 & Equal rates \\
\hline
\end{tabular}

trees with the Bayesian topology). These partial trees do not contradict the Bayesian phylogeny; they are simply unable to resolve certain relationships and many clades are not recovered with good bootstrap support.

Since there were no incompatibilities between the Bayesian tree of the entire data set and each of the remaining trees, we will concentrate in the analysis of that tree. We recovered seven major lineages, also recognized by Doadrio and Carmona (2004): four Iberian clades (the C. toxostoma, C. lemmingii, C. polylepis, and C. arcasii groups), named after a member species; and three Euro-asian groups (the $C$. nasus and $C$. soetta groups, and the monospecific $C$. genei lineage).

Chondrostoma genei is basal to all Chondrostoma species. The first bifurcation separates the Iberian species from the remaining. In the Iberian clade, the basal position is occupied by the Spanish species C. miegii, C. arrigonis and C. turiense (toxostoma lineage). Although we did not have samples of $C$. toxostoma all previous studies stressed its close proximity to the remaining members of this group (e.g. Durand et al., 2003; Doadrio and Carmona, 2004), so we assume that it very likely belongs in this clade. The remaining species of the Iberian group form a clade that is sister to the toxostoma group. This clade splits into two branches: one comprising the lemmingii lineage ( $C$. lusitanicum, $C$. almacai, $C$. oretanum and $C$. lemmingii), the other comprises two sister clades. $C$. arcasii, C. oligolepis, C. occidentale and the undescribed $C$. sp. form the arcasii lineage. Its sister is the polylepis lineage which includes the large bodied and straight mouth Iberian species $C$. duriense, C. polylepis and C. willkommii. The non-Iberian clade, that groups the remaining species included in the analysis, splits into two sister groups. In one of them the Italian $C$. soetta groups with the species C. knerii and C. phoxinus from Bosnia (soetta lineage). The sister clade contains the central European C. nasus and the related species $C$. oxyrhynchum, $C$. prespense and C. vardarense (nasus lineage). Since in previous studies this nasus lineage has been always consistently recovered based on the cyt $b$ gene, we assume that it is likely that this group includes $C$. nasus and all the remaining species of the Balkans, Anatolia and Mesopotamia.

The tree discussed above, was already anticipated although with weaker support by the study of Doadrio and Carmona (2004) and fully resolves the phylogeny of the genus. Partial trees are less resolved although some clades were recovered when using all gene fragments and methods (see supplementary material). The same holds for the monophyly of the genus Chondrostoma, and its relationship with Telestes and the more distantly related Rutilus.

The character distribution of the horny layer on the lower lip and ventral position of the mouth are coincidental (Fig. 2a). For all characters examined, except fin rays, the Iberian $C$. lemmingii and $C$. arcasii groups exhibit character states similar to those inferred for the common ancestor of the genus. Yet this appears to be due, at least in some cases, not to the retention of but a reversal to the ancestral state of the genus, i.e., these lineages exhibit a non-ventral mouth with no horny layer (as outgroups and inferred ancestor). The ancestor of the Iberian Chondrostoma is inferred to exhibit a ventral mouth with a horny layer on the lower lip, as most species of the genus. It is noteworthy that while the arcasii group is most closely related to the polylepis group, it often exhibits character states quite different from its sister group, yet similar to other Iberian Chondrostoma, e.g., absence of horny lip, arched mouth, low number of anal and dorsal fin rays. The polylepis group tends to resemble the non-Iberian groups. The morphological characters that were studied, and which are frequently used for species description in Chondrostoma, appear to be quite labile within the genus. A thick horny layer on the lower lip evolved at least twice from a thinner one, and perhaps once from an ancestor with no horny lip. A straight mouth also evolved several times from an arched condition, apparently often accompanying the thickening of the lower lip. Finally, the high lateral scale counts, typical of large bodied Chond- 


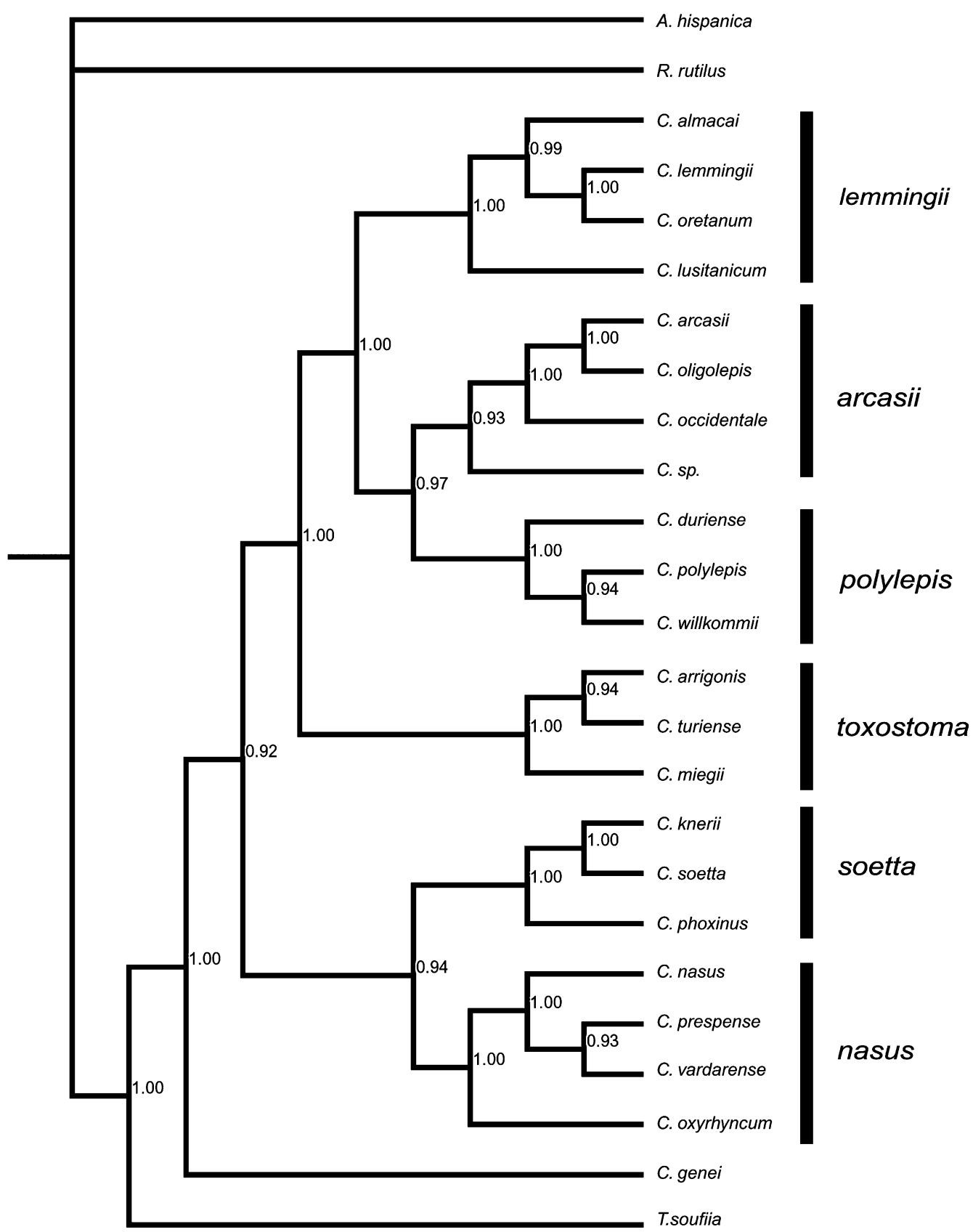

Fig. 1. Bayesian tree with posterior probabilities representing the phylogeny of the genus Chondrostoma. Lineages referred in the text are represented by black bars on the right.

rostoma, also arose recurrently from lower counts, common in small bodied Chondrostoma.

\section{Discussion}

The high level of resolution obtained with the full data set using Bayesian analysis, together with its compatibility with the trees derived from the different data subsets using MP and ME, clearly rules out the hypothesis that we are faced with a simultaneous formation of multiple lineages from the same ancestor in the phylogeny of Chondrostoma. This conclusion had been previously argued by Doadrio and Carmona (2004) who, using the cyt $b$ gene alone, had obtained a broadly similar, albeit less well-supported, Bayesian tree of the genus. The fact that much more mitochondrial data and a nuclear gene confirm and strengthen their finding is, in our view, good evidence that the dichotomous resolution is not an artefact.

Obviously, the rejection of a hard polytomy is not in itself proof that a rapid succession of branching events did not take place. The hypothesis of Durand et al. (2003) assumes that the basic cladogenic events in Chondrostoma took place in a very short period in the Messinian period, when most of the Mediterranean coastal area was a series of freshwater bodies. Such a hypothesis is compatible with a rapid succession of dichotomous events; temporally so 

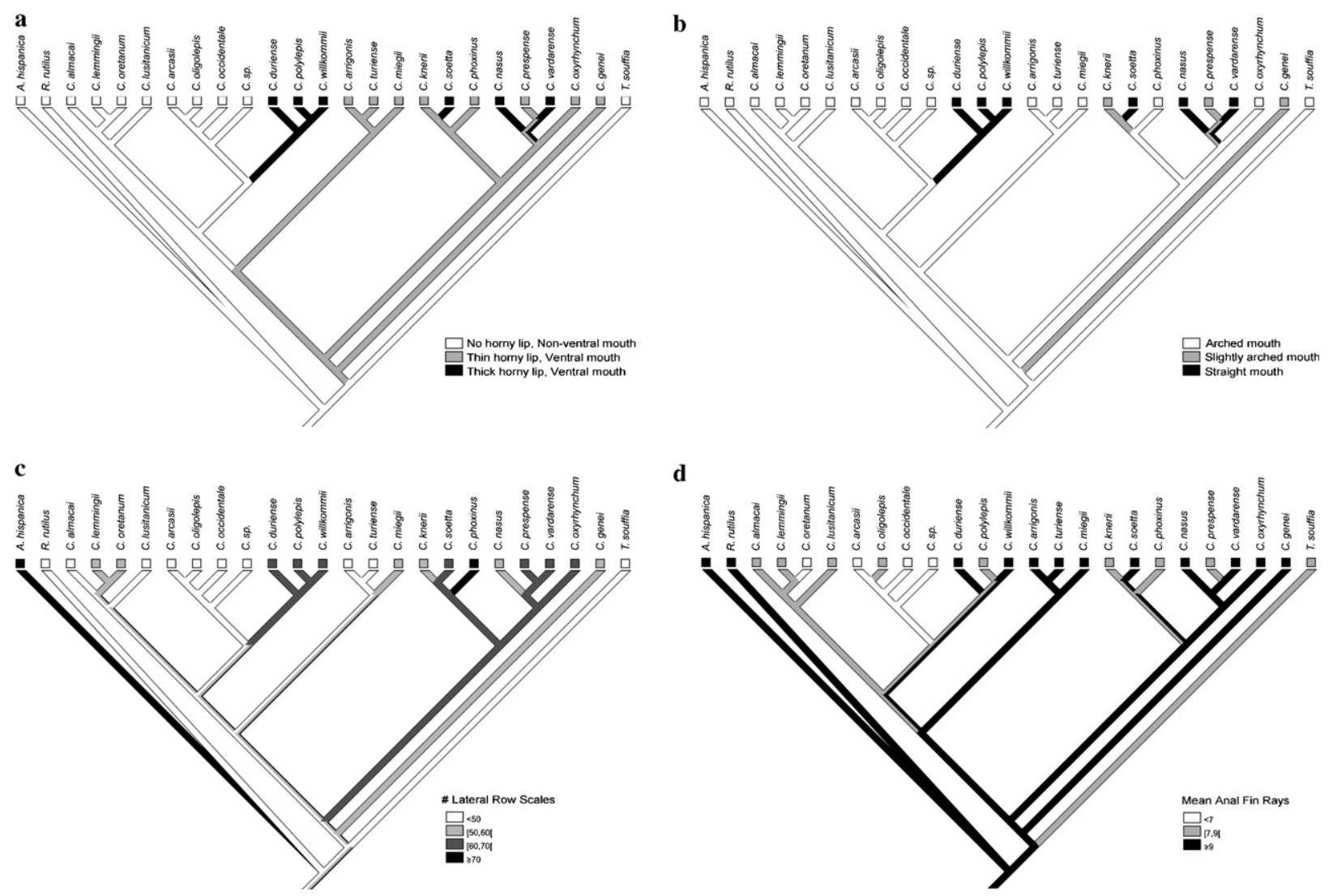

Fig. 2. Character mapping of mouth features (a and b), lateral row scales (c) and anal fin rays (d).

close that with less data they were not resolved. However, when we compare the timing of the major cladogenic events, obtained with the correct application of the same molecular clock as Doadrio and Carmona (2004), we find that the basal radiation in the Chondrostoma occurred much earlier than the Messinian, about 12 MYA. Enforcing this molecular clock upon the Bayesian phylogeny indicates that the Iberian Chondrostoma originated more than 11 MYA, shortly after the origin of the entire clade. Doadrio and Carmona (2004) also showed that the different Chondrostoma lineages diversified at considerably different times (e.g., 7 MYA for the arcasii lineage to 3 MYA for the C. toxostoma lineage), thus rejecting the idea of an almost simultaneous radiation in the Messinian.

In the Iberian Peninsula, fossil cyprinids date to the Oligocene (De la Peña, 1995) and fossils apparently belonging to the genus Chondrostoma are found in Miocene deposits before the Messinian (Doadrio, unpublished). The timing of the splits between the different Iberian lineages, are also much older than the Messinian, a fact also previously noted by Doadrio and Carmona (2004). All together, the available evidence points to a radiation of Chondrostoma prior to the Messinian.

The Bayesian phylogenetic hypothesis also has interesting biogeographic implications. We will address briefly the situation of the different groups. Iberian Chondrostoma: The arcasii lineage speciated in north and central Iberia, as a consequence of historical events involving the extensive endorheic lagoon system present in the area during the Cenozoic (Robalo et al., 2006b). Its sister clade, the lemmingii lineage, occurs from the Tagus to the south and southwest. Sister to these clades, the toxostoma lineage occurs mainly in the Mediterranean rivers of eastern Spain with the related $C$. toxostoma in south and central France. The Iberian Peninsula seems to have been the area with the highest level of diversification of major lineages of Chondrostoma. In addition, the almost non-overlapping distributions of the arcasii, lemmingii and toxostoma groups suggest that they evolved in allopatry, although secondary contacts are presently found in some rivers (Doadrio, 2001).

Italobalkanic lineages. C. genei and the soetta clade occur in an area around the central part of north Mediterranean. The genetic distance between these nearly sympatric clades suggests that rather than being the product of a dispersal during the Lago Mare phase of the Messinian, these groups may be the remnants of a much more widespread fauna occurring in Central Europe. Interestingly, basal species of other lineages of cyprinids and cobitids are found in this region, from north Italy to western Balkans, including Croatia, Bosnia and Albania (Ludwig et al., 2001; Perdices and Doadrio, 2001; Sanjur et al., 2003). Some cyprinid lineages have high levels of diversity in this area and a new genus was recently described (Freyhof et al., 2006). All these findings support the view that the freshwater ichthyofauna of this region is considerably old, may have been relatively spared by glaciations, and may have had a wider 
distribution in Central Europe, before the Plio-Pleistocene cooling.

Nasus lineage. This clade presents a distribution ranging from the Middle East to Western Europe, reaching the North Sea. How may one explain such a broad east-west distribution? In western Europe, the group is represented only by $C$. nasus. The greatest radiation of the clade occurred in the eastern part of its range. Like many other cyprinid lineages the nasus lineage must have dispersed from the Danube and its surroundings, and then probably invaded Western Europe (through the Rhine) during the Pleistocene (Banarescu, 1989). The distributions of other lineages like Rutilus, Squalius, Alburnus, among others, define similar pictures (Banarescu, 1989; Zardoya and Doadrio, 1999; Sanjur et al., 2003): they are highly diverse in southeastern Europe, particularly in Greece, yet one species ranges more broadly into west and even northern Europe (e.g., R. rutilus, Squalius cephalus and Alburnus alburnus). It is possible that the nasus group evolved in the Paratethys Sea. Interestingly, a member of the nasus clade presents the ancestral condition of arched mouth and occupies a basal position in the group, C. oxyrhynchum, occurs in waters draining to the Caspian Sea (which is a derivative of the Paratethys Sea, together with the Black Sea, Briggs, 1995). This Paratethyan origin would also explain the distribution of $C$. nasus, a fish typical of the Danube (a river draining into the Black sea) and of the Rhine (that may have received it from the Danube). The group may have invaded Greece and Turkey through Pliocenic river captures, which are well-documented for other fish taxa (e.g., Squalius, Sanjur et al., 2003).

Such a scenario raises an interesting question. Often, when discussing the models of colonization of Europe by cyprinids, we think of the fauna of Central Europe as it is now. It may well be, however, that the fish species we see presently in Central Europe are basically a recent product of migrations from the east and that much of the original fauna was extirpated by the successive glaciations of the Pleistocene. If other taxa support this hypothesis, opposing "perimediterranean" versus "central European" dispersals may be a false dilemma.

The ideas discussed above bear directly on the evolution of the genus Chondrostoma. The evolution of mouth structures and lateral scale counts suggested by Fig. 2 implies recurrent evolution of a ventral rasping mouth reinforced by a horny layer that forms a cutting edge on the lower lip and its change from a curved to a straight line, which is the more derived condition. In the Iberian clade, it is impressive to find that the more specialized forms of the polylepis group hybridize with species of the arcasii group (which its characterized by lower scale counts, near terminal mouth and absence of horny layer), originating apparently fertile hybrids (Gante et al., 2004). Members of the C. polylepis and $C$. nasus groups share traits that lack an obvious relationship with feeding, unlike the structure of the mouth, including high lateral scale count, large size, and migration of breeding fish to headwaters to spawn.
How can one explain the repeated evolution of so many traits? One alternative to convergent evolution is that these traits introgressed into the ancestral lineage of the polylepis group by hybridization. Assuming our earlier proposal of extinction of much of the pre-glacial fauna of central Europe, there may well have been, former contacts among ancestors of the Iberian arcasii-polylepis groups with fish closer to C. nasus, originating hybrid lineages in Iberia. Alternatively, the polylepis group, distributed on the western part of the Iberian Peninsula, may have resulted from an ancient introgression by members of the toxostoma group, which occupies the eastern part of the Peninsula. The species of this group also have large bodies, perform reproductive migrations to headwaters and possess a rasping mouth with a horny layer - albeit an arched one. In this latter scenario, the straight mouth of the polylepis group would be a derived condition.

Judging from the present behaviour of the fish involved, this scenario seems less likely, as there is no record of hybridization between members of the polylepis and toxostoma lineages when they occur in sympatry, whereas the toxostoma and arcasii lineages do hybridize (Doadrio, unpublished). Finally, parallel evolution of large body and high scale counts in the polylepis and nasus groups cannot be ruled out with the data presently available, even if reasons for such recurrent change are unclear. Only studies with multiple unlinked nuclear markers may help to decide between the hypotheses of past hybridization and parallel evolution. However, past hybridization should not be invoked to explain the failure of previous studies to resolve the phylogeny of the group, as all of them dealt with mitochondrial DNA that, in principle, has not recombined.

The present study supports the view that the genus Chondrostoma needs a major taxonomic revision. It shows that the morphological characters traditionally used to define the genus are labile and probably evolved several times in distinct lineages. The discrepancies evident in the literature concerning the delimitation of the genus, the conflicts between molecular and morphological data, and the fact that different clades originated at different times are, in our view, arguments against the traditional definition of Chondrostoma. We believe that the best way to resolve this complicated situation is to restrict the scope of the genus, erecting a number of new genera that form well defined monophyletic groups, and for which molecular and morphological criteria are in agreement. It may be argued that this study is not a revision of the genus, as 13 of the 35 species of Chondrostoma were not included in the analysis. This risk is however minimized if we consider that of the 13 species absent in the present study, six had already been studied from a molecular perspective, using the cyt $b$ gene. As mentioned above, $C$. toxostoma forms a very well defined clade with $C$. miegii, $C$. arrigonis and C. turiense (Doadrio and Carmona, 2004). Five other species (C. angorense, C. cyri, C. holmwoodii, C. meandrense and $C$. regium) are integrated without ambiguities in 
the clade that contains C. nasus (Durand et al., 2003; Doadrio and Carmona, 2004). Thus, there are seven species for which molecular information is lacking. These are, however, a cohesive group in morphological terms (Bogutskaya, 1997; Elvira, 1997) that share the traits possessed by all members of the C. nasus group for which molecular data exists. In addition, all seven species are distributed in the eastern part of the range of Chondrostoma (Turkey and nearby areas). Thus, it is very unlikely that further molecular studies of this seven species will affect the genera defined below, which are mainly Iberian in distribution, with an italo-balkanic taxon. When all these arguments are considered, it becomes clear that the species group for which we reserve the name Chondrostoma in our proposal is the only one that may eventually be affected by future molecular analysis. We believe that taking the risk of advancing the recognition of new genera, which are supported by molecular and morphological data, is preferable to the current situation. Indeed, at present, ichthyologists are faced with two incongruent alternatives: (1) defining the genus on morphological grounds, as adopted by Elvira $(1987,1997)$ makes the genus paraphyletic; (2) the definition of the genus on pure molecular grounds suffers from the same lack of information for the seven species, as yet unstudied genetically and generates a morphologically very heterogeneous taxa.

Our proposal of classification is as follows:

\subsection{Genus Chondrostoma Agassiz, 1832}

Type species. Cyprinus nasus L., 1758

Etymology referring to the characteristic horny layer on the lower lip.

Included species. Chondrostoma nasus (L., 1758); Chondrostoma soetta Bonaparte, 1840; Chondrostoma knerii Heckel, 1843; Chondrostoma phoxinus Heckel, 1843; Chondrostoma regium (Heckel, 1843); Chondrostoma variabile Jakowlew, 1870; Chondrostoma oxyrhynchum Kessler, 1877; Chondrostoma cyri Kessler, 1877; Chondrostoma holmwoodii (Boulenger, 1896); Chondrostoma colchicum Derjugin, 1899; Chondrostoma kubanicum Berg, 1914; Chondrostoma kinzelbachi Krupp, 1985; Chondrostoma angorense, Elvira, 1986; Chondrostoma meandrense Elvira, 1986; Chondrostoma scodrensis Elvira, 1986; Chondrostoma beysehirense Bogutskaya, 1997; Chondrostoma vardarense Karaman, 1928; Chondrostoma orientale Blanco and Banarescu, 1982; Chondrostoma prespense Karaman, 1924.

Diagnosis. Straight or arched mouth with horny layer on the lower lip; without ascendent process on premaxilla; dentary with a coronoid process anteriorly orientated and with a short anterior process; ethmoides wider than long; 52-78 canaliculated scales on the lateral line; 7-12 scales above the lateral line; 5-6 scales below the lateral line; 8 branched rays in the ventral fin; 7-10 branched rays in the dorsal fin; 8-11 branched rays in the anal fin; 7-5/5-6 pharyngeal teeth; 19-36 gill rackers on the first branchial arch. Upper branch from fifth ceratobranchial enlarged.
Distribution. From the Rhine, Danube and Po basins to the east reaching southwest Iran.

\subsection{Genus Achondrostoma N. Gen}

Type species. Leuciscus (Leucos) arcasii Steindachner, 1866

Etymology referring to the absence of horny plate on the mouth.

Included species. Achondrostoma arcasii (Steindachner, 1866), Achondrostoma oligolepis (Robalo et al., 2005), Achondrostoma occidentale (Robalo et al., 2005).

Diagnosis. Arched mouth without horny layer on the lower lip; process from premaxilla well developed and upward oriented; dentary with a coronoid process posteriorly oriented and with a long anterior process; lengh of the ethmoides greater than the width; 33-46 canaliculated scales on the lateral line; 6-8 scales above the lateral line; 2 4 scales below the lateral line; 7-8 branched rays in the ventral fin; 7 branched rays in the dorsal fin; 7 branched rays in the anal fin; 5-5 pharyngeal teeth; $10-15$ gill rackers on the first branchial arch. Upper branch of fifth ceratobranchial not enlarged.

Distribution. Endemic from North and central Iberian Peninsula, ranging from the Atlantic eastwards to the Mediterranean.

\subsection{Genus Iberochondrostoma N. Gen}

Type species. Leuciscus lemmingii Steindachner, 1866

Etymology referring to Iberian Peninsula where this genus is distributed.

Included species. Iberochondrostostoma lemmingii (Steindachner, 1866); Iberochondrostoma lusitanicum (Collares-Pereira, 1980); Iberochondrostoma oretanum (Doadrio and Carmona, 2003); Iberochondrostoma almacai (Coelho et al., 2005).

Diagnosis. Arched mouth without horny layer on the lower lip; well developed and upward orientated process from premaxilla; dentary with a coronoid process posterioly orientated and with a long anterior process; length of the ethmoides greater than the width; 46-60 canaliculated scales on the lateral line; 11-12 scales above the lateral line; 5-6 scales below the lateral line; 7-8 branched rays in the ventral fin; 6-7 branched rays in the dorsal fin; 6-7 branched rays in the anal fin; 6-5/5 pharyngeal teeth; 24-27 gill rakers on the first branchial arch. Upper branch of fifth ceratobranchial enlarged.

Distribution. Endemic from South and Central Iberian Peninsula on Atlantic slope.

\subsection{Genus Pseudochondrostoma N. Gen}

Type species. Chondrostoma polylepis Steindachner, 1865 Etymology refers to its morphological similarity with the genus Chondrostoma as consequence of homoplasy in multiple traits. 
Included species. Pseudochondrostoma polylepis (Steindachner, 1865); Pseudochondrostoma willkommii (Steindachner, 1866); Pseudochondrostoma duriense (Coelho, 1985).

Diagnosis. Straight mouth with horny layer on the lower lip; well developed and upturned process from premaxilla; dentary with a coronoid process anteriorly orientated and with a short anterior process; ethmoides wider than long; 59-78 canaliculated scales on the lateral line; $10-12$ scales above the lateral line; 4-6 scales below the lateral line; 8 branched rays in the ventral fin; 8-9 branched rays in the dorsal fin; 8-10 branched rays in the anal fin; 7-5/5-6 pharyngeal teeth; $19-35$ gill rakers on the first branchial arch. Upper branch of fifth ceratobranchial enlarged.

Distribution. Endemic from the Atlantic slope of the Iberian Peninsula.

\subsection{Genus Protochondrostoma N. Gen}

Type species. Leuciscus genei Bonaparte, 1939

Etymology from the basal position of this genus in the group of genera that formerly comprised Chondrostoma. 939).

Diagnosis. Horny layer on the lower lip; arched mouth; dentary with the coronoid process anteriorly orientated and short anterior process; premaxilla with anterior process well developed and anteriorly orientated; ethmoides more wide that long; 50-62 canaliculated scales on the lateral line; 8-9 scales above the lateral line; 4-6 scales below the lateral line; 8 branched rays in the ventral fin; 8 branched rays in the dorsal fin; 9-10 branched rays in the anal fin; 5-5 pharyngeal teeth; 14-18 gill rackers on the first branchial arch. Distribution: Po and Adige Basins in Italy and Slovenia.

\subsection{Genus Parachondrostoma N. Gen}

Type species. Chondrostoma miegii Steindachner, 1866

Etymology refers to the combination of traits that are similar to those of Chondrostoma with others that emphasize tha distinctiveness of the two genera.

Included species. Parachondrostoma toxostoma (Vallot, 1837); Parachondrostoma miegii (Steindachner, 1866); Parachondrostoma arrigonis (Steindachner, 1866); Parachondrostoma turiense (Elvira, 1986).

Diagnosis. Horny layer on the lower lip; arched mouth; dentary with the coronoid process anteriorly orientated and short anterior process; premaxilla with anterior process well developed and upward oriented; ethmoides wider than long; 44-62 canaliculated scales on the lateral line; 7-9 scales above the lateral line; 4-6 scales below the lateral line; 8 branched rays in the ventral fin; 8 branched rays in the dorsal fin; $8-11$ branched rays in the anal fin; 7-5/6-5 pharyngeal teeth; 16-35 gill rakers on the first branchial arch.

Distribution. Central and North Mediterranean rivers from the Iberian Peninsula and Loire, Garonne, Adour, Herault, Rhône Aude and Var in France.
Key to Genera

1

With horny layer on the lower lip

Without horny layer on the lower lip

2

Without ascendent process in premaxilla

Chondrostoma

With ascendent process in premaxilla

3

3

Straight mouth

Pseudochondrostoma

Arched mouth

4

4

Ascendent process of premaxilla oriented anteriorly

Ascendent process of premaxilla orientated upward

5

33-46 Canaliculated scales on the lateral line

46-60 Canaliculated scales on the lateral line

Protochondrostoma

Parachondrostoma

Achondrostoma

Iberochondrostoma

\section{Acknowledgments}

Direccão Geral das Florestas provided the necessary permits for field work in Portugal. We appreciate the skilful technical assistance provided by C. Sousa Santos and V. Domingues. We thank M. Kottelat for his critical and very useful comments. This study was funded by the projects "Evolution of feeding and agonistic behaviour in cyprinid fishes of the genus Chondrostoma" (funded by ISPA), Plurianual Program (Fundação para a Ciência e Tecnologia, FCT, UI\& D 331/94, partially FEDER funded) and CGL2004-0077 (CICYT). A. Levy was supported by an FCT Grant (SFRH/BPD/18067/2004).

\section{Appendix A. Supplementary data}

Supplementary data associated with this article can be found, in the online version, at doi:10.1016/j.ympev. 2006.07.003.

\section{References}

Almada, F., Almada, V.C., Guillemaud, T., Wirtz, P., 2005. Phylogenetic relationships of the north-eastern Atlantic and Mediterranean blennids. Biol. J. Lin. Soc. 86, 283-295.

Banarescu, P., 1989. Zoogeography and history of the freshwater fish faune of Europe. In: Holcik, J. (Ed.), The Freshwater Fishes of Europe, vol. 1. AULA-Verlag, Wiesbaden, pp. 80-107.

Banarescu, P., 1992. Zoogeography of fresh waters Distribution and dispersal of freshwater animals in North America and Eurasia (Vol. II). Aula Verlag, Wiesbaden.

Banarescu, P., Coad, B.W., 1991. Cyprinids of Eurasia. In: Winfield, I.J., Nelson, J.S. (Eds.), Cyprinid Fishes. Systematics, Biology and Exploitation. Chapman and Hall, London, pp. 127-155. 
Bianco, P.G., 1990. Potential role of the palaeohistory of the Mediterranean and Paratethis basins on the early dispersal of Euro-Mediterranean freshwater fishes. Ichthyol. Explor. Freshwaters 1, 167-184.

Briggs, J.C., 1995. Global biogeography - developments in palaeontology and stratigraphy. Elsevier, Arnoldsville.

Brito, R.M., Briolay, J., Galtier, N., Bouvet, Y., Coelho, M.M., 1997. Phylogenetic relationships within genus Leuciscus (Pisces, Cyprinidae) in Portuguese fresh waters, based on mitochondrial Cytochrome $b$ sequences. Mol. Phylogenet. Evol. 8, 435-442.

Bogutskaya, N.G., 1997. Chondrostoma beysehirense, a new cyprinid fish from Beysehir Lake, central Turkey. Ichthyol. Explor. Freshwaters 8, $151-158$.

Coelho, M.M., Mesquita, N., Collares-Pereira, M.J., 2005. Chondrostoma almacai, a new cyprinid species from the southwest of Portugal, Iberian Peninsula. Folia Zool. 54, 201-212.

Collares-Pereira, M.J., 1980. Les Chondrostoma à bouche arquée de la Péninsule Ibérique (avec la description de C. lusitanicum nov. sp.) (Poissons, Cyprinidae). C. R. Acad. Sc. Paris, sér. D. 291, 275-278.

Collares-Pereira, M.J., 1983. Estudo sistemático e citogenético dos pequenos ciprinídeos ibéricos pertencentes aos géneros Chondrostoma Agassiz 1835, Rutilus Rafinesque, 1820 e Anaecypris Collares-Pereira, 1893. $\mathrm{Ph} . \mathrm{D}$. Thesis, Universidade de Lisboa.

Cunha, C., Coelho, M.M., Carmona, J.A., Doadrio, I., 2004. Phylogeographical insights into the origins of the Squalius alburnoides complex via multiple hybridization events. Mol. Ecol. 13, 2807-2817.

De la Peña, A., 1995. Tertiary fishes from the iberian continental basins: history and fossil record. Coloquios de Paleontología 47, 25-47.

Doadrio, I., 2001. Atlas y libro rojo de los peces continentales de España.Dirección General de la Natureza - Museo Nacional de Ciencias Naturales, Madrid.

Doadrio, I., Carmona, J.A., 2003a. A new species of the genus Chondrostoma Agassiz, 1832 (Actinopterygii, Cyprinidae) from the Iberian Peninsula. Graellsia 59, 29-36.

Doadrio, I., Carmona, J.A., 2003b. Testing freshwater Lago Mare dispersal theory on the phylogeny relationships of Iberian cyprinid genera Chondrostoma and Squalius (Cypriniformes, Cyprinidae). Graellsia 59, 457-473.

Doadrio, I., Carmona, J.A., 2004. Phylogenetic relationships and biogeography of the genus Chondrostoma inferred from mitochondrial DNA sequences. Mol. Phylogenet. Evol. 33, 802-815.

Durand, J.D., Bianco, P.G., Laroche, J., Gilles, A., 2003. Insight into the origin of endemic Mediterranean ichthyofauna-Phylogeography of Chondrostoma genus (Teleostean, Cyprinidae). J. Hered. 94, 315-328.

Elvira, B., 1987. Taxonomic revision of the genus Chondrostoma Agassiz, 1835 (Pisces, Cyprinidae). Cybium 11, 111-149.

Elvira, B., 1997. Taxonomy of the genus Chondrostoma (Osteichthyes, Cyprinidae): an updated review. Folia Zool. 46 (Suppl. 1), 1-14.

Farris, J.S., Källersjö, M., Kluge, A.G., Bult, C., 1995. Testing significance of incongruence. Cladistics 10, 315-319.

Felsenstein, J., 1985. Confidence limits on phylogenies: an approach using the bootstrap. Evolution 39, 783-791.

Freyhof, J., Lieckfeldt, D., Bogutskaya, N.G., Pitra, C., Ludwig, A., 2006. Phylogenetic position of the Dalmatian genus Phoxinellus and description of the newly proposed genus Delminichthys (Teleostei: Cyprinidae). Mol. Phylogenet. Evol. 38, 416-425.

Gante, H.F., Collares-Pereira, M.J., Coelho, M.M., 2004. Introgressive hybridisation between two Iberian Chondrostoma species (Teleostei, Cyprinidae) revisited: new evidence from morphology, mitochondrial DNA, allozymes and NOR-phenotypes. Folia Zool. 53, 423-432.

Howes, G.J., 1991. Systematics and biogeography: an overview. In: Winfield, I.J., Nelson, J.S. (Eds.), Cyprinid fishes-systematics.
In: Biology and Exploitation, vol. 3. Chapman and Hall, London, pp. 1-33.

Kishino, H., Hasegawa, M., 1989. Evaluation of the maximum-likelihood estimate of the evolutionary tree topologies from DNAsequence data, and the branching order in Hominoidea. J. Mol. Evol. 29, 170-179.

Liu, H., Tzeng, C., Teng, H., 2002. Sequence variations in the mitochondrial DNA control region and their implications for the phylogeny of the Cypriniformes. Can. J. Zool. 80, 569-581.

Ludwig, A., Bohlen, J., Wolter, C., Pitra, C., 2001. Phylogenetic relationships and historical biogeography of spined loaches (Cobitidae, Cobitis and Sabanejewia) as indicated by variability of mitochondrial DNA. Zool. J. Lin. Soc. 131, 381-392.

Maddison, W.P., Maddison, D.R. 2005. Mesquite: a modular system for evolutionary analysis. Version $1.06<\mathrm{http} / / /$ mesquiteproject.org $>$.

Nelson, J.S., 2006. Fishes of the world, 4th Ed. Wiley, New York, USA.

Page, R.D.M., Holmes, E.C., 1998. Molecular evolution: a phylogenetic approach. Blackwell Publishers, Oxford.

Poe, S., Chubb, A.L., 2004. Birds in a bush: five genes indicates explosive evolution of avian orders. Evolution 58, 404-415.

Perdices, A., Doadrio, I., 2001. The molecular systematics and biogeography of the European cobitids based on mitochondrial DNA sequences. Mol. Phylogenet. Evol. 19, 468-478.

Posada, D., Crandall, K.A., 1998. Modeltest: testing the model of DNA substitution (v.3.6). Bioinformatics 14, 817-818.

Robalo, J., Almada, V., Santos, C., Moreira, M.I., Doadrio, I., 2005. New species of the genus Chondrostoma Agassiz, 1832 (Actynopterigii, Cyprinidae) from western Portugal. Graellsia 61, 19-29.

Robalo, J.I., Sousa-Santos, C., Levy, A., Almada, V.C., 2006a. Molecular insights on the taxonomic position of the paternal ancestor of the Squalius alburnoides hybridogenetic complex. Mol. Phylogen. Evol. 39, 276-281.

Robalo, J.I., Sousa-Santos, C., Almada, V.C., Doadrio, I., 2006b. Paleobiogeography of two Iberian endemic cyprinid fishes (Chondrostoma arcasii-Chondrostoma macrolepidotum) inferred from sequence data. J. Hered. 97, 143-149.

Ronquist, F., Huelsenbeck, J.P., 2003. MRBAYES 3: Bayesian phylogenetic inference under mixed models. Bioinformatics 19, 1572-1574.

Sambrook, J., Fritsch, E.F., Maniatis, T., 1989. Molecular cloning: a laboratory manual, second ed. Cold Spring Harbor Laboratory Press, Cold Spring Harbor, NY.

Sanjur, O., Carmona, J.A., Doadrio, I., 2003. Molecular phylogeny of Iberian chub (genus Squalius, Cyprinidae), inferred from molecular data. Mol. Phylogenet. Evol. 29, 20-30.

Schmidt, T.R., Gold, J.R., 1993. Complete sequence of the mitochondrial cytochrome $b$ gene in the Cherryfin Shinner, Liturus roseipinnis (Teleostei: Cyprinidae). Copeia 3, 880-883.

Slowinski, J.B., 2001. Molecular Polytomies. Mol. Phylogenet. Evol. 19, $114-120$.

Shimodaira, H., Hasegawa, M., 1999. Multiple comparisons of log-likelihoods with applications to phylogenetic inference. Mol. Biol. Evol. 16, 1114-1116.

Swofford, D.L., 1998. PAUP*: phylogenetic analysis using parsimony (* and other methods) version 4.0. Sinauer Associated, Sunderland, MA.

Zardoya, R., Doadrio, I., 1999. Molecular evidence on the evolutionary and biogeographical patterns of European cyprinids. J. Mol. Evol. 49, 227-237.

Zardoya, R., Doadrio, I., 1998. Phylogenetic relationships of Iberian cyprinids: systematic and biogeographical implications. Proc. R. Soc. Lond. B 265, 1365-1372. 